\title{
Distributions of arsenic and selenium in selected Chinese coal mines
}

\author{
Bin He, Lina Liang, Guibin Jiang* \\ Research Center for Eco-Environmental Sciences, Chinese Academy of Sciences, P.O. Box 2871, 100085 Beijing, PR China
}

Received 6 August 2001; accepted 5 December 2001

\begin{abstract}
The contents of arsenic and selenium in 33 coals collected from the main coal mines in northeastern, northern and eastern China were determined by flow injection-hydride generation and non-dispersion atomic fluorescence spectrometry (HGAFS). The concentrations of As in the northeast region are relatively higher with the values $>100$ $\mu \mathrm{g} \mathrm{g}^{-1}$; in the east they are lower with values $<100 \mu \mathrm{g} \mathrm{g}^{-1}$. The contents of Se in these three areas are the opposite, most of them from the northeast mines are $<1 \mu \mathrm{g} \mathrm{g}^{-1}$ and increase as the mine location advances south where the average contents are $>5 \mu \mathrm{g} \mathrm{g}^{-1}$.
\end{abstract}

(c) 2002 Elsevier Science B.V. All rights reserved.

Keywords: Coal samples; Arsenic; Selenium; Distribution

\section{Introduction}

China is one of the world's largest coal producers and consumers. The proven coal deposits amount to 966.7 billion tons, of which the explored deposits so far are approximately 110 billion tons, and the production rate in 2000 was 1.4 billion tons. In China $75 \%$ of energy needs come from coal combustion and this situation will last for another 50 years. The Chinese thermal power has been playing a greater role in the Chinese electric power industry. In the next 20 years more coalfired power plants may be built in China than in the rest of the world because of population growth

\footnotetext{
*Corresponding author. Fax: + 86-10-6292-3563.

E-mail address: gbjiang@mail.rcees.ac.cn (G. Jiang).
}

and industrialization (Yan et al., 1999). Apart from power plants the domestic use of raw coal is popular. In China more than $50 \%$ of the energy needs for urban households are provided by coal stoves and small coal boilers and $22 \%$ of rural households rely on coal, this means there are several hundred million people who commonly burn raw coal in the home.

However, coal is not a clean energy, it contains many potentially toxic compounds as organic compounds and trace elements (Rodushkin et al., 2000; Silva et al., 1999; Gentzis and Goodarzi, 2000). Throughout the world, coal-fired power plants and domestic coal boilers produce large quantities of waste. The gaseous and aerosol pollutants in the flue gases from coal combustion, and the leachable constituents in coal ash cause serious environmen- 
Table 1

Experimental conditions and program for $\mathrm{HG}-\mathrm{AFS}$

\begin{tabular}{lll}
\hline Element & As & Se \\
\hline Hydride generation & & \\
$\mathrm{KBH}_{4}$ concentration & $2.5 \%$ & $2.0 \%$ \\
$\mathrm{HCl}$ concentration & $1.2 \mathrm{~mol} \mathrm{1}$ & $1.2 \mathrm{~mol}^{-1}$ \\
Sampling time & $5 \mathrm{~s}$ & $5 \mathrm{~s}$ \\
Hydride generation time & $16 \mathrm{~s}$ & $22 \mathrm{~s}$ \\
AFS & & Hollow cathode lamp, $196.0 \mathrm{~nm}$ \\
Lamp & Hollow cathode lamp, $193.7 \mathrm{~nm}$ & $320 \mathrm{~V}$ \\
PMT voltage & $270 \mathrm{~V}$ & $60 \mathrm{~mA}$ \\
Primary current & $60 \mathrm{~mA}$ & Argon, $400 \mathrm{ml} 1^{-1}$ \\
Carrier gas & Argon, $400 \mathrm{ml} 1^{-1}$ & \\
\hline
\end{tabular}

tal pollution, especially in homes where coal is used for heating and cooking. Some coals have undergone diagenetic development causing their enrichment in potentially toxic trace elements such as arsenic, mercury, selenium and antimony. Many aquatic and terrestrial habitats close to areas of waste production and disposal become contaminated with these trace elements, potentially impacting to biota (Hopkins et al., 1998; Stoewsand et al., 1990; Besser et al., 1996). People exposed chronically to these toxic trace elements can develop various chronic or acute diseases, such as typical symptoms of As poisoning, hair loss, selenosis etc. (Finkelman, 1999; Swaine, 2000; Finkelman et al., 1999; Oryszczyn et al., 1996). Domestic use of coal can potentially present serious human health problems because the coals generally are mined locally with little regard to their composition, and the coals are commonly burned in poorly vented or unvented stoves, directly exposing residents to the emissions.

Better knowledge of coal quality parameters may help to reduce some of these health problems. For example, information on concentrations and distributions of potentially toxic elements in coal may delineate areas of a coal deposit to be avoided and may help to anticipate the behavior of these elements during coal benefication, combustion, weathering and leaching.

This work focuses attention upon the determination of As and Se by flow injection-hydride generation-atomic fluorescence spectrometry and their distributions in coal samples collected from east, northeast and north China.

\section{Experimental}

\subsection{Instrumentation}

Arsenic and Se were determined by an AF610A atomic fluorescence spectrophotometer (Beijing Ruili Analytical Instrument Co., Beijing, China) at 193.7 and $196.0 \mathrm{~nm}$ line source, respectively. The hollow cathode lamps were operated at $270 \mathrm{~V}$ for As and $320 \mathrm{~V}$ for Se of PMT voltage. The primary current was set at $60 \mathrm{~mA}$ for both elements. Argon was used as carrier and separating gas and the flow rate of it was set at $400 \mathrm{ml}$ $\min ^{-1}$. Sample introduction and hydride generation was accomplished in an intermittent flow injection mode. A personal computer fitted with AFS 610 software was used for the control of the AFS and the integration of the peak areas. The experimental conditions as well as sampling and hydride generation program were listed in Table 1 .

\subsection{Reagents}

A Se stock solution, $1000 \mu \mathrm{g} \mathrm{ml} \mathrm{m}^{-1}$, was prepared by weighing $0.1405 \mathrm{~g}$ of $\mathrm{SeO}_{2}$ (Beijing Chemical Factory, China) in $25 \mathrm{ml}$ of $4.8 \mathrm{~mol}$ $1^{-1} \mathrm{HCl}$ and diluted to $100 \mathrm{ml}$ with de-ionized water.

An As aqueous standard stock solution of 1000 $\mu \mathrm{g} \mathrm{ml}^{-1}$ was prepared by dissolving $0.5654 \mathrm{~g}$ of $\mathrm{Na}_{3} \mathrm{AsO}_{4} \cdot 12 \mathrm{H}_{2} \mathrm{O}$ (Beijing Chemical Factory, China) in $25 \mathrm{ml}$ of $4.8 \mathrm{~mol} \mathrm{l}^{-1}$ MOS (metal oxide semiconductor) level $\mathrm{HCl}$ and diluted to $100 \mathrm{ml}$ with de-ionized water. 
These stock solutions were diluted and acidified with $1.2 \mathrm{~mol} 1^{-1} \mathrm{HCl}$ daily to form the final standard solution in the $\mathrm{ng} \mathrm{ml} \mathrm{ml}^{-1}$ concentration range.

$\mathrm{KBH}_{4}$ solutions were prepared daily by dissolving $\mathrm{KBH}_{4}$ in $0.2 \% \mathrm{KOH}$ and $1.2 \mathrm{~mol} \mathrm{l}^{-1}$ of $\mathrm{HCl}$ was used for the acidification of sample.

\subsection{Sample preparation}

Coal samples were collected from the main coal mines located in northeastern, northern and eastern of China, as shown in Fig. 1. The samples were prepared by grinding, and screening through 150mesh sieve. The homogenized sample was dried in an oven at $100{ }^{\circ} \mathrm{C}$ for $2 \mathrm{~h}$ and then stored in a desiccator.

A $0.1000 \mathrm{~g}$ portion of finely ground coal sample was weighed into a 30-ml Teflon container, and then $1 \mathrm{ml}$ concentrated $\mathrm{HNO}_{3}, 1 \mathrm{ml}$ concentrated $\mathrm{HClO}_{4}$ and $0.5 \mathrm{ml}$ concentrated $\mathrm{HF}$ were added in sequence. The container was then covered with a Teflon cover and placed in a stainless steel bomb. The bomb was sealed tightly with a screw closure to avoid gas leakage and placed in an oven heated at $180{ }^{\circ} \mathrm{C}$ for $8 \mathrm{~h}$. After cooling, the container was taken out of the bomb and placed on an electric stove without a cover and the temperature was maintained at $90{ }^{\circ} \mathrm{C}$ until approximately $0.5 \mathrm{ml}$ of solution remained. The $\mathrm{Se}$ was reduced to $\mathrm{Se}^{\mathrm{IV}}$ by adding $2 \mathrm{ml}$ of $6 \mathrm{~mol}^{-1} \mathrm{HCl}$ and kept at $90{ }^{\circ} \mathrm{C}$ for $30 \mathrm{~min}$. The solution was diluted to $10 \mathrm{ml}$ with $1.2 \mathrm{~mol} \mathrm{l}^{-1} \mathrm{HCl}$ for final analysis.

\section{Results and discussion}

\subsection{Effect of $\mathrm{HCl}$ and $\mathrm{KBH}_{4}$ concentrations}

Since a boosted discharge hollow cathode lamp was used for excitation, atomic fluorescence spectrometry was suitable for routine analysis (Corns et al., 1993) and hydride generation-atomic fluorescence spectrometry (HG-AFS) was used for the determination of As (Segura et al., 1999; Featherstone et al., 1998; Feng and Fu, 1998) and $\mathrm{Se}$ (He et al., 1998; Feng and Fu, 1998; Rico Varade and Luque de Castro, 1998) due to its excellent sensitivity. It was found that $\mathrm{HCl}$ was the most suitable medium in which the fluorescence signals of the As and Se were more stable and more intense. Moreover, the only criterion applied to the As and Se of the optimum $\mathrm{KBH}_{4}$ concentrations is the best sensitivity that can be obtained in general. The concentrations of $\mathrm{HCl}$ and $\mathrm{KBH}_{4}$ affect both of the hydride generation process and the burning of the atomizer flame which is supported by hydrogen produced during hydride generation. The influences of acid and reductant concentrations on the determination were studied. Results in Fig. 2 and Fig. 3 indicate that the recoveries of As is complete when the concentration of acid and $\mathrm{KBH}_{4}$ is $1.2 \mathrm{~mol}^{-1}$ and $2.5 \%$, while for Se the acidity has no effect and the reductant concentration should be $2 \%$ to achieve complete recovery. These results may relate to the insufficient hydride generation of $\mathrm{AsH}_{3}$ and $\mathrm{SeH}_{4}$ at lower acidity and $\mathrm{KBH}_{4}$. While at higher concentrations of $\mathrm{HCl}$ and/or $\mathrm{KBH}_{4}$ redundant hydrogen produced in hydride generation results in an unstable of atomizer flame which leads to high noise background and poor detection sensitivity. We chose $1.2 \mathrm{~mol} \mathrm{l}^{-1} \mathrm{HCl}$ for the sample acidification and for As and Se concentrations of $2.5 \%$ and $2.0 \% \mathrm{KBH}_{4}$ were chosen, respectively.

\subsection{Effect of argon gas flow rate}

Argon in AFS is used both as a carrier gas and one of the components of the argon-hydrogen flame. The hydrides are separated by the argon from matrix in a gas-liquid separator and swept into a small argon-hydrogen flame that is selfignited at the electrothermal wire fitted on the quartz tube outlet of atomizer. The flow rate of Ar was demonstrated to influence the peak response of both $\mathrm{AsH}_{3}$ and $\mathrm{SeH}_{4}$. At lower flow rates the base of the flame tended to sit inside the tube orifice and the hydrides were not swept completely to the flame due to insufficient gas velocities. While when the flow rate is higher than $500 \mathrm{ml}$ $\min ^{-1}$, dilution of the analytes may be cause, and the residence time of the analyte atoms in the optical path was shortened which would lead to decrease the intensity of fluorescence and lower 

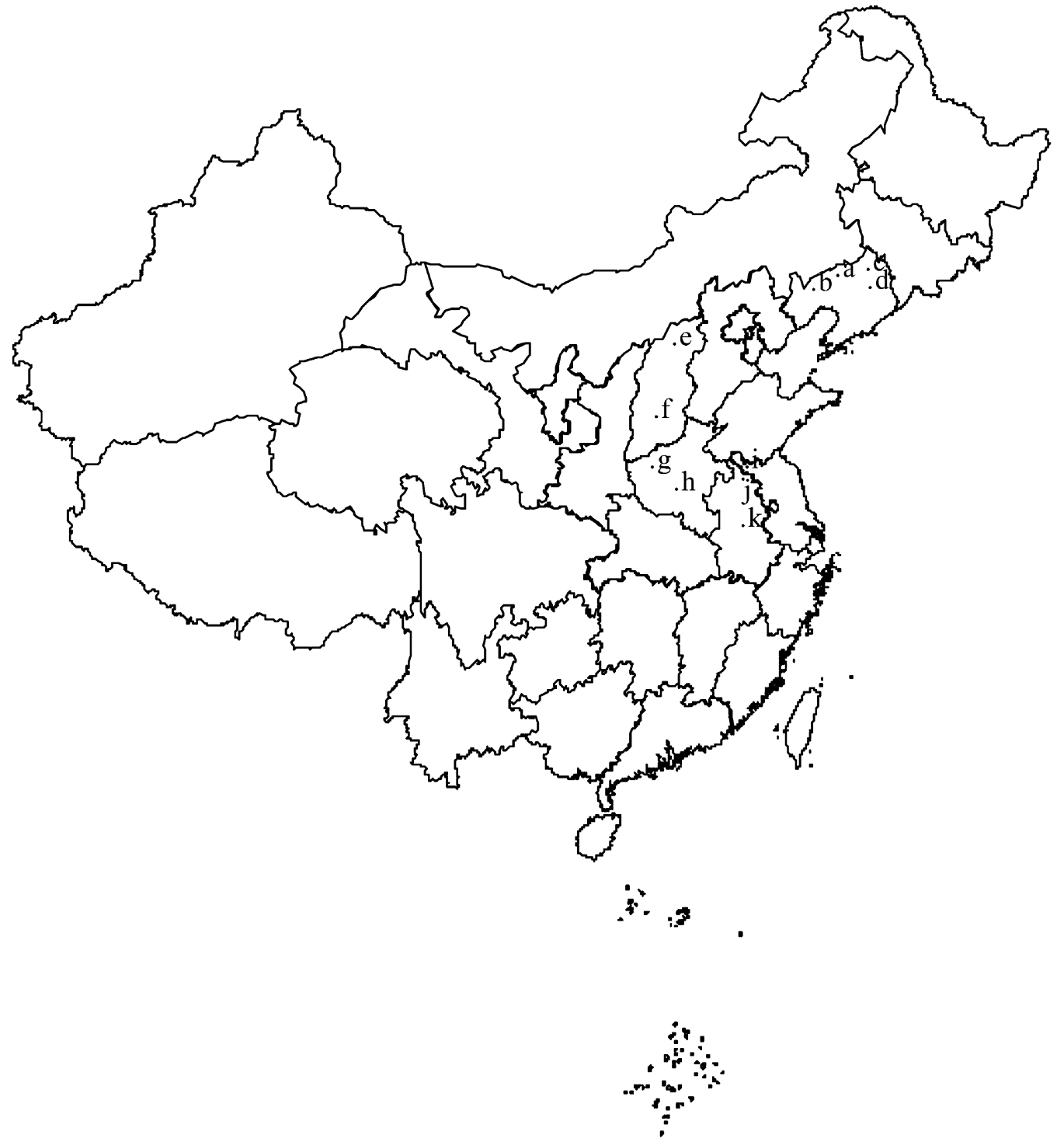

Fig. 1. The map of China with an indication of the sampling places: (a) Fuxin, sample A1-A4; (b) Beipiao, sample B1 and B2; (c) Tiefa, sample C1 and C2; (d) Fushun, sample D1 and D2; (e) Shuozhou, sample E1-E3; (f) Huozhou, sample F1-F4; (g) Yima, sample G1 and G2; (h) Pingdingshan, sample H1-H3; (i) Xuzhou, sample I1-I3; (j) Huaibei, sample J1-J3; (k) Huainan, sample K1-K5.

the peak response. Results, shown in Fig. 4, indicated that a flow rate of $400 \mathrm{ml} \mathrm{min}{ }^{-1}$ was optimum for both As and Se and, thus, this flow rate is chosen through the experiment.

\subsection{Analytical figures of merit}

Under the optimal concentrations of $\mathrm{HCl}$ and $\mathrm{KBH}_{4}$ and the flow rate of argon, the quantitative 


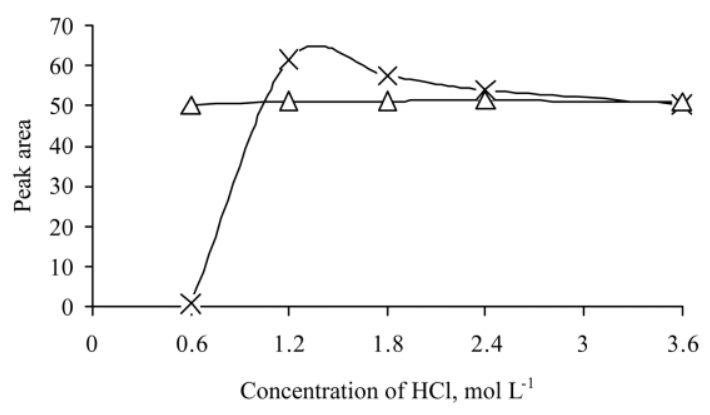

Fig. 2. Influence of the concentration of $\mathrm{HCl}$ on the hydride generation efficiency of $\mathrm{As}(X)$ and $\mathrm{Se}(\Delta)$.

determinations were performed with plotting calibration curves. The regression equations for the calibrated curves were constructed for both analytes, $y=13.975 x-2.197$ with a correlation coefficient of 0.9998 and $y=12.410 x-3.105$ with a relative coefficient of 0.9999 were obtained for As and $\mathrm{Se}$, respectively. The detection limits were 0.4 $\mathrm{ng} \mathrm{ml} \mathrm{m}^{-1}$ for As and $0.6 \mathrm{ng} \mathrm{ml}^{-1}$ for Se, while the relative standard deviations of eleven replicate determinations were $2.7 \%$ for As and $2.1 \%$ for Se.

\subsection{Sample analysis}

To evaluate quality of the proposed analytical method, well established reference material is required to carry out a comparative analysis. The determination of As and Se was performed in reference material coal fly ash GBW08401 using the proposed procedure. The results of $10.90 \pm 0.58$ $\mu \mathrm{g} \mathrm{g}^{-1}$ for As and $1.06 \pm 0.05 \mu \mathrm{g} \mathrm{g} \mathrm{g}^{-1}$ for $\mathrm{Se}$ agreed well with the certified values, which are $11.4 \pm 0.6 \mu \mathrm{g} \mathrm{g}^{-1}$ for As and $1.13 \pm 0.16 \mu \mathrm{g} \mathrm{g}^{-1}$ for Se, respectively.

Table 2 summarizes the results for the contents of As and Se in coal sample from 33 coal mines; the contents of As and Se are different according to the coal mine location.

The highest As contents were found in the B1 mine of $133.12 \pm 21.69 \mu \mathrm{g} \mathrm{g}^{-1}$ and $\mathrm{F} 1$ mine of $136.45 \pm 2.74 \mu \mathrm{g} \mathrm{g}^{-1}$. Although the lowest concentrations of As of $55.71 \pm 2.32 \mu \mathrm{g} \mathrm{g}^{-1}$ and $61.35 \pm 0.72 \mu \mathrm{g} \mathrm{g}^{-1}$ were found in Teifa, the mean level is lower in east China. The mean concentrations of As were higher in northeast and north

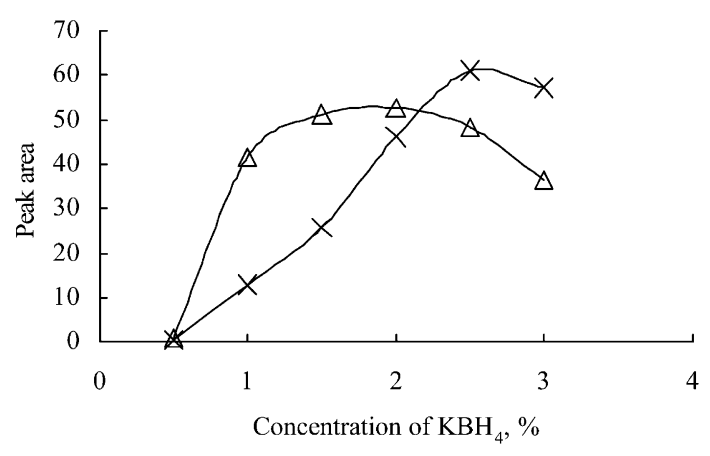

Fig. 3. Influence of the concentration of $\mathrm{KBH}_{4}$ on the hydride generation efficiency of As $(X)$ and Se (?)

China and decreases as the mine location advances south. It is accepted that the trace elements occurrence, distribution and content level differ from one coal to others, because of the different coalification processed (Yan et al., 1999). On the one hand, the concentration of As is in a direct ratio to the coalification level and the existence of pyrite, which is higher in northeast China as reported (Ren et al., 1999; Zhang et al., 1992). On the other hand, during coalification processes the humus, which is much higher in east China, hindered the concentration of As (Xu et al., 1990; Zhuang et al., 1999).

Selenium distribution is related to the type of rock, especially igneous rock, and carbonaceous shales which are enriched in east China (Ren et al., 1999), rather than being related to the coalifi-

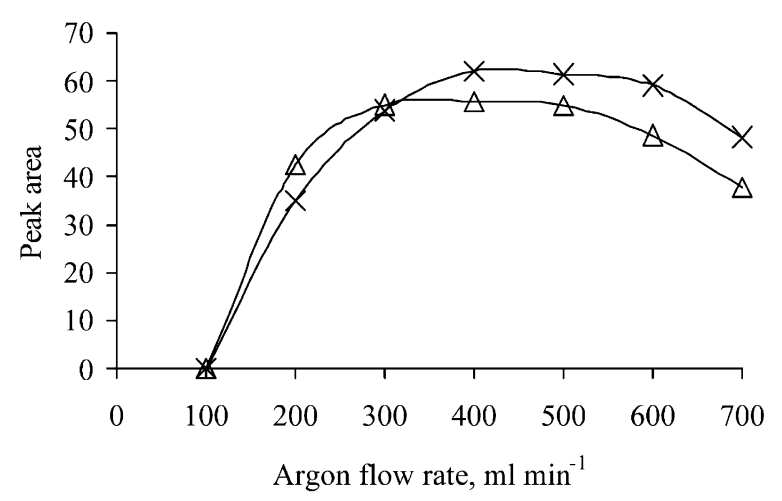

Fig. 4. Influence of argon flow rate on the peak areas of As $(\times)$ and $\mathrm{Se}(?)$ 
Table 2

Results of determination of As and Se contents in coal samples

\begin{tabular}{|c|c|c|c|}
\hline & Sample location & As $(\mu \mathrm{g} / \mathrm{g})$ & $\operatorname{Se}(\mu \mathrm{g} / \mathrm{g})$ \\
\hline \multirow[t]{10}{*}{ Northeast China } & A1 & $104.02 \pm 1.23$ & $0.65 \pm 0.02$ \\
\hline & $\mathrm{A} 2$ & $129.43 \pm 9.36$ & $0.44 \pm 0.02$ \\
\hline & A3 & $122.48 \pm 8.60$ & $0.24 \pm 0.04$ \\
\hline & A4 & $113.27 \pm 5.00$ & $0.28 \pm 0.02$ \\
\hline & B1 & $133.12 \pm 21.69$ & $0.15 \pm 0.01$ \\
\hline & B2 & $113.11 \pm 2.71$ & $0.22 \pm 0.02$ \\
\hline & $\mathrm{C} 1$ & $55.71 \pm 2.32$ & $0.38 \pm 0.03$ \\
\hline & $\mathrm{C} 2$ & $61.35 \pm 0.72$ & $0.28 \pm 0.01$ \\
\hline & D1 & $114.74 \pm 8.15$ & $1.41 \pm 0.04$ \\
\hline & D2 & $111.37 \pm 1.61$ & $0.88 \pm 0.05$ \\
\hline \multirow[t]{12}{*}{ North China } & E1 & $102.86 \pm 2.51$ & $2.61 \pm 0.10$ \\
\hline & E2 & $103.25 \pm 1.39$ & $3.66 \pm 0.11$ \\
\hline & E3 & $102.13 \pm 7.40$ & $3.79 \pm 0.11$ \\
\hline & $\mathrm{F} 1$ & $136.45 \pm 2.74$ & $2.87 \pm 0.10$ \\
\hline & $\mathrm{F} 2$ & $122.26 \pm 8.33$ & $2.39 \pm 0.09$ \\
\hline & $\mathrm{F} 3$ & $156.72 \pm 7.55$ & $2.16 \pm 0.02$ \\
\hline & F4 & $110.74 \pm 2.23$ & $2.15 \pm 0.14$ \\
\hline & G1 & $117.53 \pm 4.22$ & $0.41 \pm 0.03$ \\
\hline & $\mathrm{G} 2$ & $118.88 \pm 7.25$ & $0.37 \pm 0.03$ \\
\hline & H1 & $61.74 \pm 5.33$ & $5.18 \pm 0.20$ \\
\hline & $\mathrm{H} 2$ & $74.02 \pm 0.33$ & $4.86 \pm 0.20$ \\
\hline & $\mathrm{H} 3$ & $66.85 \pm 3.81$ & $4.45 \pm 0.43$ \\
\hline \multirow[t]{11}{*}{ East China } & I1 & $69.82 \pm 5.46$ & $4.36 \pm 0.09$ \\
\hline & $\mathrm{I} 2$ & $66.39 \pm 4.11$ & $7.19 \pm 0.21$ \\
\hline & I3 & $67.95 \pm 1.51$ & $7.24 \pm 0.12$ \\
\hline & $\mathrm{J} 1$ & $86.85 \pm 5.46$ & $5.49 \pm 0.20$ \\
\hline & $\mathrm{J} 2$ & $81.04 \pm 1.01$ & $5.24 \pm 0.11$ \\
\hline & $\mathrm{J} 3$ & $98.32 \pm 2.64$ & $5.18 \pm 0.21$ \\
\hline & $\mathrm{K} 1$ & $89.35 \pm 5.58$ & $6.01 \pm 0.24$ \\
\hline & $\mathrm{K} 2$ & $92.13 \pm 1.90$ & $5.90 \pm 0.24$ \\
\hline & K3 & $92.41 \pm 4.63$ & $6.03 \pm 0.26$ \\
\hline & K4 & $74.90 \pm 3.24$ & $5.25 \pm 0.80$ \\
\hline & K5 & $71.99 \pm 0.68$ & $5.55 \pm 0.81$ \\
\hline
\end{tabular}

cation process. Data obtained show that most of the Se levels in northeast China are lower than 1 $\mu \mathrm{g} \mathrm{g}^{-1}$ and in east China are higher than $5 \mu \mathrm{g}$ $\mathrm{g}^{-1}$. These results agreed well with the conclusion reported early that $\mathrm{Se}$ distribution in the middle zone from northeast to southwest China is lower, and in the northwest and southeast China it is higher.

Among 26 trace elements that are considered to be of environmental interest, As and Se rank of most important environmental concern, especially As, which is potentially highly hazardous to the environment when it released from coal during coal mining, beneficiation and combustion (Finkelman, 1999). During coal mining, As and Se are released from the pyrite and carbonaceous shales and contaminates nearby water. In the process of beneficiation of coal to produce cleaned coal, although significant reductions in the levels of various trace elements are found, for example, As could be reduced by approximately $54-75 \%$ and Se by approximately $14-34 \%$, there is an associated increase in trace element contents in the reject material. The disposal of these washery rejects must be subjected to careful treatment because their increased contents in pyrite and carbonate are the potential source of acidic solutions that could contaminate local waters and, hence, increase concentration of As and Se. The need for constant vigilance is illustrated by a serious outbreak of ill 
health in north China's Inner Mongolia, where is adjacent to Shanxi province. The ill health is caused by excess of As in drinking water from underground wells where the As concentrations are between $0.01-1.86 \mathrm{mg} \mathrm{l}^{-1}$. More than half of the well water has an As content above the maximum permissible limit recommended by the WHO of $0.05 \mathrm{mg}^{-1}$ (Zhang et al., 1994; Fan et al., 1993). The well-water is used by the local people for drinking, cooking and other household purposes and most of the As-related clinical manifestations such as melanosis, depigmentation, keratosis, hyperkeratosis, gangrene and malignant neoplasms are observed amongst the affected people. During coal combustion, up to approximately $80 \%$ of original mineral matter is in the fly ash. In most power plants, fly ash is conveyed through the system where most of it is removed by electrostatic precipitation on fabric filters. However, in some places of China where raw coal is used for domestic heating and cooking, thousands of people suffer from As and Se poisoning caused by coal combustion. Typical symptoms of arsenosis including hyperpigmentation, Bowen's disease and squamous cell carcinoma and selenosis such as alopecia and nail loss are observed (Zheng et al., 1992, 1996).

Distinct from As, Se level in human has no direct relation to the exposure time in a high $\mathrm{Se}$ environment. Selenosis is attributed to the practice of using combustion ash as a soil amendment. This process introduced large amounts of Se into the soil and resulted in Se uptake by crops. Available Se will not upset plant growth, but too much may produce plants and crops that could upset grazing animals and humans, as observed in the east Chinese city, Enshi, Hubei province, where the content of Se in soil is up to $213 \mu \mathrm{g} \mathrm{kg}^{-1}$ (Wang and Peng, 1988).

The interest in trace elements in coals is not only because of their potential to be harmful, but also because of their essentiality. Studies have shown that when Se which is released from disposal of fly ash to the aquatic environment, or in such a way that aqueous ash leachates enters aquatic environments, mercury bioaccumulation in fish may be substantially lower than what might otherwise occur (Southworth et al., 1994; Paulsson and Lundbergh, 1991) as Se has an antagonism to mercury. A dramatic incidence of Se deficiency occurs in some parts of China, especially northeast and north China, where it is so low in the human diet that there is widespread heart disease, known as Keshan and Kaschin-Beck disease, which may affect millions of people (Peng and Xu, 1986).

\section{Conclusion}

The contents of As and Se in 33 coal samples selected from main coal mines located in northeast, north and east China were determined by AFS under the optimal analytical conditions. The results show that the As levels in northeast and north China are commonly higher and decreased slightly as the mine location advances south. However, the concentrations of Se are significantly lower in northeast China and increase promptly as the mine location advances south.

Knowing the concentration of the potentially toxic elements in coal will help determine if use of the coal might present a health risk because of an association with environmental issues and the health of plants, animals and humans in relation to both harmful and essential impacts. Furthermore, knowledge of the distribution of the elements in a coal deposit will permit for intelligent decisions regarding mining all or parts of a deposit. Those with higher values are examined closely before use in order to ensure that many toxic trace elements problems are under control during coal mining, cleaning, burning and the treatment of fly ash.

\section{Acknowledgments}

This work was supported by the National Natural Science Foundation of China (29825114) and the Chinese Academy of Sciences (KZCX2-410, 414)

\section{References}

Besser JM, Giesy JP, Brown RW, Buell JM, Dawson GA. Selenium bioaccumulation and hazards in a fish community affected by coal fly ash effluent. Ecotoxicol. Environ. Saf. 1996;35:7-15. 
Corns WT, Stockwell PS, Ebdon L, Hill SJ. Development of an atomic fluorescence spectrometer for the hydride-forming elements. J. Anal. At. Spectrom. 1993;8:71-77.

Fan C, NarenG, Zhang Y, Zhang G, Li H, Dai Q, Zhou Y, Ma L, Luo Z. Determination of arsenic content and study of its enrich factors in drinking water of the west area in Huhhot Basin. Environment and Health(Ch.) 1993; 10:56-58

Featherstone AM, Butler ECV, O'Grady BV, Michel P. Determination of arsenic species in sea-water by hydride generation atomic fluorescence spectroscopy. J. Anal. At. Spectrom. 1998;13:1355-1360.

Feng XJ, Fu B. Determination of arsenic, antimony, selenium, tellurium and bismuth in nickel metal by hydride generation atomic fluorescence spectrometry. Anal. Chim. Acta 1998;371:109-113.

Finkelman RB, Belkin HE, Zheng BS. Health impacts of domestic coal use in China. Proc. Natl. Acad. Sci. USA 1999;96:3427-3431.

Finkelman RB. Trace elements in coal environmental and health significance. Biol. Trace Elem. Res. 1999;67:197204.

Gentzis T, Goodarzi F. Effect of geological processes on coal quality and utilization potential: review with examples from western Canada. J. Hazardous Materials 2000;74:109-124.

He Y, Moreda-Pineiro J, Cervera ML, de la Guardia M. Direct determination of dissolved selenium(IV) and selenium(VI) in sea-water by continuous flow hydride generation atomic fluorescence spectrometry. J. Anal. At. Spectrom. 1998;13:289-293.

Hopkins WA, Mendonce MT, Rowe CL, Congdon JD. Elevated trace element concentrations in southern toads, Bufo Terrestris, exposed to coal combustion waste. Arch. Environ. Contam. Toxicol. 1998;35:325-329.

Oryszczyn MP, Godin J, Frette C, Hellier G, Bertrand JP, et al. Decrease in selenium status in relation to coal dust exposure. Am. J. Ind. Med. 1996;30:281-284.

Paulsson K, Lundbergh K. Treatment of mercury contaminated fish by selenium addition. Water Air and Soil Pollut. 1991;56:833-841.

Peng A, Xu L. Study on antagonism of selenium and humic acid. Science in China (Series B) (Ch.) 1986;6:635-641.

Ren D, Xu D, Zhang J, Zhao F, Li G, Xie L. Distribution of associated elements in coals from Shenbei coalfield. J. China Uni. Mining \& Technol. (Ch.) 1999;28:5-8.

Rico Varade CM, Luque de Castro MD. Determination of selenium in solid samples by continuous subcritical water extraction, flow injection derivatisation and atomic fluorescence detection. J. Anal. At. Spectrom. 1998;13:787-791.
Rodushkin I, Axelsson MD, Burman E. Multielement analysis of coal by ICP techniques using solution nebulization and laser ablation. Talanta 2000;51:743-759.

Segura M, Madrde Y, Camara C. Evaluation of atomic fluorescence and atomic absorption spectrometric techniques for the determination of arsenic in wine and beer by direct hydride generation sample introduction. J. Anal. At. Spectrom. 1999; $14: 131-135$.

Silva MM, Goreti M, Vale R, Caramao EB. Slurry sampling graphite furnace atomic absorption spectrometry: determination of trace metals in mineral coal. Talanta 1999;50:1035-1043.

Southworth GR, Peterson MJ, Turner RR. Changes in concentrations of selenium and mercury in largemouth bass following elimination of fly ash discharge to a quarry. Chemosphere 1994;29:71-79.

Stoewsand GS, Anderson JL, Weinstein LH, Osmeloski JF, Gutenmann WH, Lisk DJ. Selenium in tissues of rats fed rutabagas grown on soil covering a coal fly ash landfill. Bull. Environ. Contam. Toxicol. 1990;44:681-685.

Swaine DJ. Why trace elements are important. Fuel Processing Technol. 2000;65-66:21-33.

Wang Z, Peng A. Species determination of Selenium in environmental samples. Fenxi Huaxue (Ch.) 1988;16:644646.

Xu Q, Han D, Jin K, Ren D, Zheng Y. Correlation of coal constituents and coalification degree versus contents 49 kinds of elements in coal of China. J. China Uni. Mining and Technol. (Ch.) 1990;19:48-57.

Yan R, Lu X, Zeng H. Trace elements in Chinese coals and their partitioning during coal combustion. Combust. Sci. \& Tech. 1999; 145:57-81.

Zhang Z, Fan J, Jin J, Yang Y, Song L, Yang H. Mode of occurrence of arsenic, lead, beryllium and chromium in coal. J. Fuel Chem. \& Technol. (Ch.) 1992;20:206-211.

Zhang Y, Ma L, Luo Z, Zhang G, Fan C, Naren G. Water quality analysis of arsenic enriched groundwater in large area of western Huhhot Basin. Rural Eco-Environment (Ch.) 1994;10:59-61.

Zheng B, Yu X, Zhand J, Zhou D. Environmental geochemistry of coal and endemic arsenism in southwest Guizhou, PR China. 30 ${ }^{\text {th }}$ Intl. Geologic Congress Abstr., 1996;3:410.

Zheng B, Hong Y, Zhao W, Zhou H, Xia W, Su H, et al. The Se-rich carbonaceous siliceous rock and endemic selenosis in southwest Hubei, China. Chinese Sci. Bull. 1992;37:1725-1729.

Zhuang X, Yang S, Zeng R, Xu W. Characteristics of trace elements in coals from several main coal districts in China. Geolog. Sci. \& Technol. Inf. (Ch.) 1999;18:63-66. 